\title{
EFFECTS OF MACRONUTRIENT COMPOSITION ON SPECIFIC DYNAMIC ACTION IN THE LABORATORY MOUSE, Mus musculus
}

\author{
J. K. KAGYA-AGYEMANG, E. KRÓL AND J. R. SPEAKMAN \\ (Received 23, March 2009; Revision Accepted 2, September 2009)
}

\begin{abstract}
Open-flow respirometry was used to measure the magnitude of specific dynamic action (SDA), the maximum rate of oxygen consumption and the length of time that the rate of oxygen uptake remained elevated above pre-feeding level in MF1 female mice fed different macronutrient diets. Irrespective of diet, the metabolic rate increased immediately after feeding and reached a maximum within 1.7 hours. The composition of the diet significantly altered the magnitude of SDA. SDA was highest for high protein-fed mice $(9.4 \%)$, followed by high carbohydrate-fed mice $(6.1 \%)$ and lastly high and medium fat-fed mice $(3.9 \%$ and $4.5 \%)$.
\end{abstract}

KEY WORDS: Specific dynamic action, resting metabolic rate, macronutrient diets, open-flow respirometry, respiratory quotient, energy expenditure

\section{INTRODUCTION}

The ingestion of food by an animal is followed by losses of energy as heat. As a result, many animals have a substantially increased metabolic rate following ingestion of a meal. If a fasting animal is given food within a few hours there is an exponential rise in its body heat production above the level represented by basal metabolism. This increased metabolism above resting level is termed specific dynamic action (SDA) (Blaxter, 1989; McCue, 2006) or heat increment of the food (McDonald et al., 2002). The SDA/heat increment of food may be expressed in absolute terms (MJ kg-1 food DM), or relatively as a proportion of the gross or metabolizable energy (McDonald et al., 2002). According to Kleiber (1975), SDA refers to the increased energy expenditure associated with digestion, assimilation and biosynthesis. A major route by which energy is diverted to maintenance of the soma, particularly of endotherms, is via the basal metabolic rate (BMR) (Speakman, 1997). Basal metabolic rate refers to the energy required by an animal when it is resting and not performing any metabolic work to digest food or maintain its body temperature (also called resting metabolic rate, RMR) (Speakman, 1997). For comparisons to be made between individuals that vary in mass or resting metabolism, rates of energy expenditure are often expressed relative to RMR (Speakman, 1997).

The causes of SDA/heat increment of feeding are to be found in the processes of the digestion of foods and the metabolism of nutrients derived from them. The act of eating, which includes chewing, swallowing and enzyme secretion requires muscular activity for which energy is supplied by the oxidation of nutrients (Gawecki and Jeszka, 1978; McDonald et al.,
2002). More heat is produced when nutrients are metabolised and it is worth noting that the heat increment of foods varies considerably according to the nature of the food. The ubiquity of SDA among very diverse animals suggests that it is associated with one or more fundamental aspects of food processing (McDonald et al., 2002; McCue, 2006). As a result, SDA has long been considered as "tax" on food processing (McDonald et al., 2002).

Many animal physiologists have proposed numerous terms to describe SDA, such as thermic effect of food (Whitney and Rolfes, 1996), diet-induced thermogenesis (Trier, 1996; Gabarrou et al., 1997; Swennen et al., 2006), heat increment (Blaxter, 1989; McDonald et al., 2002), calorigenic effect (Pike and Brown, 1984), and specific dynamic action (Krieger, 1978; McCue, 2006). The different terms used for SDA by different physiologists signify its complex physiological nature. The most commonly used term SDA was adopted from the German phrase (specifishdynamische wirkung) coined by Max Rubner in the 1890s (McCue, 2006). Since SDA remains the most common term to refer to this phenomenon, it will be used throughout the remainder of the present study.

SDA may be divided into an obligatory component related to digestion, absorption and processing of nutrients and into regulatory or facultative component (Jéquier, 1985). In mammals, regulatory SDA allows body weight to be maintained in spite of a large increase in food intake. This is due to the large increase in energy expenditure following feeding. Because SDA is an increase in energy expenditure following feeding, it can be characterized using metrics that offer insight into the various physiological processes underlying SDA. Most accounts of SDA utilize multiple measurements to characterize postprandial (fasting)

J. K. Kagya-Agyemang, School of Biological Sciences, University of Aberdeen, Aberdeen, AB24 2TZ, UK and Department of Animal Science Education, University of Education, Winneba, P.O. Box 40, Mampong-Ashanti, Ghana

E. Król, School of Biological Sciences, University of Aberdeen, Aberdeen, AB24 2TZ,

J. R. Speakman, School of Biological Sciences, University of Aberdeen, Aberdeen, AB24 2TZ, 
responses (McCue, 2006). Some investigators of SDA emphasize the duration of elevated metabolism while others emphasize the duration following feeding at which peak postprandial metabolism occurs (Janes and Chappell, 1995). Some measures of SDA demonstrate more bioenergetics relevance compared to others and since the energy devoted to SDA generally increase with ration and meal size, the most informative measures of SDA are those that correlate the energetic content of a meal with the total energy devoted to SDA. This is achieved (McCue, 2006) by calculating the SDA coefficient $\left(\mathrm{C}_{\mathrm{SDA}}\right)$ by dividing the energy devoted to SDA $\left(E_{S D A}\right)$ by the energy contained in the meal $\left(E_{\text {meal }}\right)$. This is expressed using the formula: $\mathrm{C}_{\mathrm{SDA}}=\left(\mathrm{E}_{\mathrm{SDA}} / \mathrm{E}_{\text {meal }}\right)^{*} 100$.

Table 1: represents $\mathrm{C}_{\mathrm{SDA}}$, and other metrics of SDA responses reported in studies of animals ingesting various meals (McCue, 2006).

Table 1: Overview of published SDA responses in mammals and birds ingesting various meals

\begin{tabular}{|c|c|c|c|c|c|c|}
\hline Animal & Meal & $\mathrm{C}_{\mathrm{SDA}}(\%)$ & Duration (h) & Scope & Time to peak & Ref. \\
\hline \multicolumn{7}{|l|}{ Mammals } \\
\hline Dog & Glucose & 5 & 5 & 1.3 & 3 & 1 \\
\hline Dog & Water & $\mathrm{n} / \mathrm{a}$ & & 1.0 & $\mathrm{n} / \mathrm{a}$ & 2 \\
\hline Dog & Olive oil & 19 & & 1.2 & 3 & 3 \\
\hline Dog (large meal) & Beef & 50 & & & & 4 \\
\hline Dog (small meal) & Beef & 32 & & & & 5 \\
\hline Dog & Beef & 45 & 22 & 1.9 & 8 & 6 \\
\hline Human & Protein & 17 & 10 & 2.0 & & 7 \\
\hline Human & Protein & 17 & & 1.2 & 3 & 8 \\
\hline Human & Glucose & 4 & & 1.2 & 3 & 9 \\
\hline Human & Fat & 4 & & 1.1 & 4 & 10 \\
\hline Rat & Beef hear & 7 & $<24$ & 1.2 & & 11 \\
\hline Rat & Gelatin & 8 & $<24$ & 1.2 & & 12 \\
\hline Rat & Casein & 13 & $<24$ & 1.3 & 1 & 13 \\
\hline Rat & Olive oil & 4 & $<24$ & 1.1 & 2 & 14 \\
\hline Rat & Starch & 4 & $<24$ & 1.3 & 2 & 15 \\
\hline Rat & Casein & & & 1.6 & 0 & 16 \\
\hline \multicolumn{7}{|l|}{ Aves } \\
\hline Penguin (chick) & Krill & 10 & 10 & 1.2 & 1 & 17 \\
\hline
\end{tabular}

$\mathrm{C}_{\mathrm{SDA}}$ refers to SDA coefficient (see text), scope refers to the maximal metabolic rate during digestion divided by the standard or basal metabolic rate of the animal and time to peak refers to the time period after feeding at which the SDA response reaches a peak level.

1. Lusk, 1912; 2. Lusk, 1915; Rapport, 1924; 3. Lusk, 1912; 4. Weiss and Rapport, 1924; 5. Weiss and Rapport, 1924; 6. William et al., 1912; 7. Bradfield and Jourdan, 1973; 8. Mason et al., 1927; 9. Mason et al., 1927; 10. Mason et al., 1927; 11. Kriss, 1938; 12. Kriss, 1938; 13. Kriss et al., 1934; Kriss, 1938; 14. Kriss et al., 1934; 15. Kriss, et al., 1934; 16 Gawecki and Jeszka, 1978; 17. Janes and Chappell, 1995.

The ability of animals to reproduce or survive is strongly influenced by energy allocation patterns (Stenseth et al., 1980; Krasov, 1986; Speakman and McQueenie, 1996; Speakman, 1997; Bacigalupe and Bozinovic, 2002; Król and Speakman, 2003a).

Many of the spatial and temporal variations in the activities of animals are centred on how to obtain, allocate and conserve energy. The balance between acquisition and expenditure of energy is critical to survival and reproductive success. This balance depends on the interplay among intake of matter and energy, digestive processing, allocation to alternative functions such as thermoregulation, growth and reproduction (Krasov, 1986; Bacigalupe and Bozinovic, 2002). Therefore, examining energy costs is central to many studies of the ecology, behaviour and evolution of mammals. Before an animal can allocate ingested energy to growth and/or activity, it must first meet maintenance costs related to daily functions and metabolism. The maintenance cost associated with food processing is called SDA and it accounts for $6-17 \%$ of the energy budget in humans (Taylor and Pye, 1966). SDA can be equivalent to $10-30 \%$ of energy from an ingested meal in other mammals such as the rats (Krieger, 1978). It can therefore have a significant effect on the amount of net assimilated energy that is available for growth and/or activity. Since SDA represents a potentially large portion of an individual's total energy budget in mammals or because SDA is an unavoidable diversion of energy that might otherwise have been directed to growth and/or activity of the animal (Kleiber, 1975; McDonald et al., 2002), a better understanding of SDA related energy expenditure or energy cost is relevant to our understanding of the nutritional ecology and evolutionary bioenergetics of mammals (Trier, 1996; McCue, 2006).

The amount of heat energy liberated per unit time is the metabolic rate. Energy expenditure can be measured directly by heat production, or inferred indirectly by the analysis of respiratory gases. Indirect calorimetry (i.e. the analysis of $\mathrm{O}_{2}$ consumption and $\mathrm{CO}_{2}$ production) is a commonly used method for estimating 
an animal's metabolic energy expenditure based on rates of oxygen $\mathrm{O}_{2}$ consumption and $\mathrm{CO}_{2}$ production (Glenne and Blair, 1995; Speakman, 1997; Arch et al., 2006). Indirect calorimetry is based on the assumption that $\mathrm{O}_{2}$ consumption $\left(\mathrm{VO}_{2}\right)$ and $\mathrm{CO}_{2}$ production $\left(\mathrm{VCO}_{2}\right)$ are closely correlated with heat production (Speakman, 1997). The ratio of $\mathrm{CO}_{2}$ production to $\mathrm{O}_{2}$ consumption $\left(\mathrm{CO}_{2} / \mathrm{O}_{2}\right)$ is known as the respiratory quotient $(\mathrm{RQ})$, and is dependent on the substrate being metabolised. If mostly fat is metabolised, $\mathrm{RQ}$ equals $0.7,1$ litre $\mathrm{O}_{2} \approx$ $19.7 \mathrm{~kJ}$, and if mainly carbohydrate is metabolised the $\mathrm{RQ}$ equals $1.0,1$ litre $\mathrm{O}_{2} \approx 20.9 \mathrm{~kJ}$ (Schmidt-Nielson, 1997). When the animal metabolizes protein, the $R Q$ is around 0.8 (Speakman, 1997). RQ can be calculated by measuring both $\mathrm{O}_{2}$ consumption and $\mathrm{CO}_{2}$ production simultaneously, or inferred from knowing the composition of the food consumed. Once $R Q$ is known, the $\mathrm{O}_{2}$ consumption or $\mathrm{CO}_{2}$ production can be converted to energy using the Weir (1949) equation:

$\mathrm{E}_{(\mathrm{cal})}=\mathrm{rCO}_{2}(\mathrm{mls} / \mathrm{min})[1.106+(3.941 / \mathrm{RQ})]$ (cited in Speakmnan, 1997 equ. 8.3).

For more than two centuries, scientists have observed and reported the increase in energy expenditure that occurs during meal digestion (McCue, 2006; Secor, 2009). From the minute copepod to the horse, this reported "cost of digestion" has been described, quantified, and experimentally investigated over a wide array of invertebrate and vertebrate taxa. However, there is no record of published SDA responses in laboratory mice despite their usage in biomedical research. This study therefore examined the hypothesis that diets with different macronutrient contents have different SDA and that quantifying the SDA of different macronutrient diets fed to female mice could explain the limits to energy intake during reproduction. Specifically, this study investigated the effects of macronutrient composition on SDA in the laboratory mouse.

\section{MAERIALS AND METHODS}

\section{Animals and experimental protocol}

Thirty two female mice (Mus musculus L.: out bred MF1) aged 15-16 weeks old were used in this study (Harlan UK Limited, Shaw's Farm, England). Each animal was housed in a "shoebox" cage $(44 \mathrm{~cm} \times 12 \mathrm{~cm}$ $x 13 \mathrm{~cm}$ ) containing sawdust and nesting material. The environment was regulated at $21^{\circ} \mathrm{C}\left( \pm 1^{\circ} \mathrm{C}\right)$ on a $12 \mathrm{~L}$ : $12 \mathrm{D}$ photoperiod with lights on at 07:00 h. Rat and mouse breeder and grower diet $(15.60 \mathrm{~kJ} / \mathrm{g}$ gross energy, $18.80 \%$ crude protein, $60.30 \%$ carbohydrate, $3.40 \%$ crude oil, $3.7 \%$ crude fibre and $3.80 \%$ ash - all values calculated to nominal $10 \%$ moisture content, Special Diets Services, BP Nutrition, Witham, UK) and water were supplied ad libitum.

\section{Specific dynamic action experimental protocol}

The resting metabolic rate (RMR) of the 32 mice were quantified from oxygen consumption $\left(\mathrm{VO}_{2}\right)$ and carbon dioxide production $\left(\mathrm{VCO}_{2}\right)$ rates at $21^{\circ} \mathrm{C}$. The animals were food deprived for $5 \mathrm{~h}$ (07:00-12:00 h) prior to measurement of $\mathrm{VO}_{2}$ and $\mathrm{VCO}_{2}$. During that period, water remained at the disposal of each animal.

RMR was measured using an open-flow respirometry system connected to a paramagnetic oxygen analyser (Servomex Ltd., Crowborough, UK) and carbon dioxide analyser. Each RMR measurement took $6.5 \mathrm{~h}$ to complete. The body mass of each mouse was recorded $( \pm 0.01 \mathrm{~g})$. Each animal was then confined in a cylindrical Perspex respirometry chamber, that contained a perforated base to separate animals from their faeces and urine, with rubber stoppers at each end (volume $885 \mathrm{ml}$ ) housed inside a constant-temperature incubator (Gallenkamp, Loughborough, UK) set at $21^{\circ} \mathrm{C}$ $\left( \pm 1^{\circ} \mathrm{C}\right)$ for $1.5 \mathrm{~h}$ without food. Four macronutrient diets, namely high protein (HP), high carbohydrate (HC), medium fat (MF) and high fat (HF) diets (Research Diets, New Brunswick, NJ, U.S.A) were randomly assigned to individual animals. The 32 animals were divided into four groups. Each group of 8 animals were randomized over the diets in such a way that each of them was fed on each of the four diets on different days in the respirometer. Specifically, the animals were given a pre-weighed amount of a specific diet for 5 consecutive hours and measures of their $\mathrm{VO}_{2}$ were continued. Atmospheric air, dried using silica gel $(\mathrm{BDH}$, UK) was drawn through the chamber (Charles Austen Pumps Ltd) at a rate of $600-800 \mathrm{ml} \mathrm{min}^{-1}$ measured using Alexander Wright flow meter (DM3A). Subsequently, a sample of ex-current air leaving the animal chamber was dried (silica gel) and directed through the gas analyser at the rate of about $150 \mathrm{ml} \mathrm{min}^{-}$ 1 . Carbon dioxide in the outflow was not absorbed prior to measurement of oxygen content since that provided the most accurate method for measuring energy expenditure (Koteja, 1996b; Speakman, 2000; Arch et al., 2006). The measurements from the oxygen analyzer were recorded directly on a microcomputer (Viglen PC) at intervals of 30 seconds and the metabolic rates corrected for standard temperature and pressure (STP) were used to estimate the RMR. Following RMR measurements, mice were removed from their respirometry chambers and the body mass of each animal recorded immediately before it was returned to its cage. The food intake of each animal was calculated as the difference between the weighed amount of dry mass food offered and leftover dry mass in chambers (both dried in a Gallenkamp oven at $60^{\circ} \mathrm{C}$ ). Immediately after each SDA trial, all mice were fed rodent chow until the next trial. In all 128 trials, respectively were completed. All animals were maintained in accordance with the United Kingdom Home Office Animals (Scientific procedures) Act 1986.

\section{Percent SDA calculation}

The periods of activity that occur during respirometry measurements tend to elevate $\mathrm{VO}_{2}$ above the level represented by basal metabolism. Oxygen consumption values obtained during the SDA trial were assumed to represent RMR plus the additional metabolic cost of digestion and increases in $\mathrm{VO}_{2}$ due to some activity occurring during measurements. Spikes of $\mathrm{VO}_{2}$ caused by periods of activity by the mouse (i.e. area A, Figure 1) when the food was placed in the chamber were obvious from the plots of $\mathrm{VO}_{2}$ over time. As a result, total SDA values were determined by plotting the $\mathrm{VO}_{2}$ curve and selecting the smooth area designated as $\mathrm{B}$ under the heat production curve but above RMR to calculate the energy devoted to SDA. 
The $\mathrm{CO}_{2}$ production over the same range as $\mathrm{VO}_{2}$ was used to calculate the $\mathrm{RQ}\left(\mathrm{VCO}_{2} / \mathrm{VO}_{2}\right)$ for each diet.

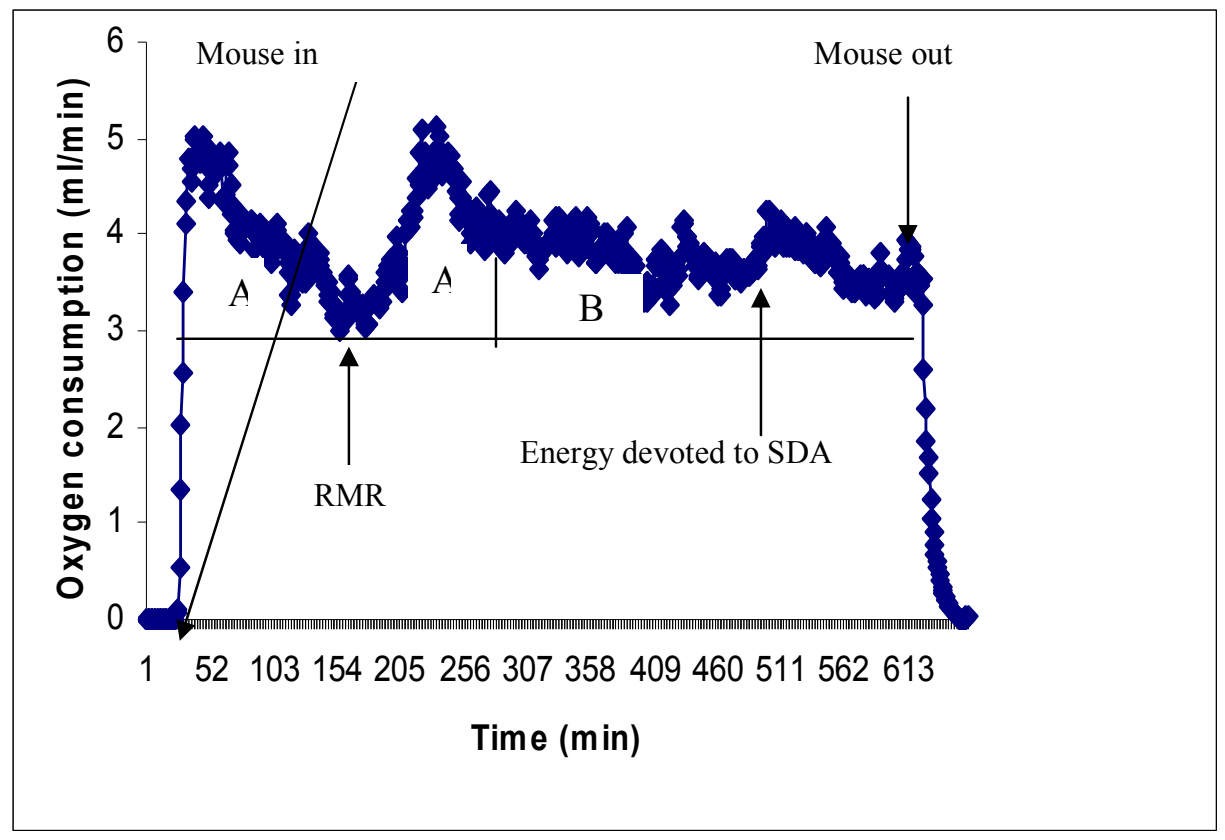

Figure 1: An example of time course of oxygen consumption of female mouse measured in an open-flow respirometry system to calculate energy devoted to specific dynamic action (SDA).

Data obtained from $\mathrm{O}_{2}$ consumption $\left(\mathrm{VO}_{2}\right)$ was converted to energy devoted to SDA using the energy equivalent of $1 \mathrm{ml} \mathrm{O}_{2}$ approximately equals $\mathrm{VO}_{2}{ }^{*}[(4+$ $\mathrm{RQ}){ }^{*}$ (4.184 Joules/min)] (Hardy, 1974). Based on this, the mean oxygen consumption of each macronutrient diet during each 30 -second period of respirometry was converted to energy using the above equation, where $\mathrm{RQ}$ is the respiratory quotient $\left(\mathrm{VCO}_{2} / \mathrm{VO}_{2}\right)$.

The mean dry mass food intake at SDA $(\mathrm{g})$ of each diet was multiplied by its gross energy content
$(\mathrm{kJ} / \mathrm{g})$ to get the mean gross energy intake at SDA $(\mathrm{kJ})$. To calculate the SDA coefficient which is a proportion of the energy intake devoted to SDA, the energy equivalent of $\mathrm{VO}_{2}$ of each macronutrient diet was divided by the mean gross energy intake of each diet. The \% SDA was then calculated by multiplying the SDA coefficient by 100.

Table 1: Composition of macronutrient diets

\begin{tabular}{|l|l|l|l|l|}
\hline Product code & DO4080301 & D12450B & D12451 & D12492 \\
\hline Diet & High protein & $\begin{array}{l}\text { High } \\
\text { carbohydrate }\end{array}$ & Medium fat & High fat \\
\hline Gross energy $\left(\mathrm{kJ} \mathrm{g}^{-1}\right)$ & 19.88 & 19.89 & 19.89 & 19.90 \\
\hline Ingredients $\left(\mathrm{g} / \mathrm{kg} \mathrm{diet}^{-1}\right.$ & & & & \\
\hline Casein & 600 & 200 & 200 & 200 \\
\hline L-cystine & 9 & 3 & 3 & 3 \\
\hline Corn starch & 112 & 315 & 72.8 & 0 \\
\hline Maltodextrin & 35 & 35 & 100 & 125 \\
\hline Sucrose & 147 & 350 & 172.8 & 68.8 \\
\hline Cellulose & 50 & 50 & 50 & 50 \\
\hline Soya oil & 25 & 25 & 25 & 25 \\
\hline Lard & 20 & 20 & 177.5 & 245 \\
\hline Mineral mix & 10 & 10 & 10 & 10 \\
\hline Dicalcium phosphate & 13 & 13 & 13 & 13 \\
\hline Calcium carbonate & 5.5 & 5.5 & 5.5 & 5.5 \\
\hline Potassium citrate & 16.5 & 16.5 & 16.5 & 16.5 \\
\hline Vitamin mix & 10 & 10 & 10 & 10 \\
\hline Choline bitartrate & 2 & 2 & 2 & 2 \\
\hline
\end{tabular}




\section{RESULTS}

Immediately a mouse was placed into the respirometry chamber, the animal had an elevated metabolic rate probably due to handling. Thereafter, the metabolic rate declined over the first $1.5 \mathrm{~h}$ or so to produce a stable basal metabolic rate (Figure1). When food was placed into the chamber, the animal again had an elevated metabolic rate. SDA is generally manifested as a pronounced increase in $\mathrm{O}_{2}$ uptake following food ingestion. The mean body mass before and after SDA, $\mathrm{O}_{2}$ consumption, $\mathrm{CO}_{2}$ production, calculated $\mathrm{RQ}$, oxygen consumption converted to energy, dry food intake, gross energy (GE) intake, SDA coefficient $\left(\mathrm{C}_{\mathrm{SDA}}\right)$ and the corresponding magnitude of SDA $\left(\mathrm{C}_{\mathrm{SDA}}, \%\right)$ in female mice fed on HP, HC, MF and HF diets, respectively are shown in Tables 2 and 3.

Table 2: Body mass of female mice and respiratory quotient of macronutrient diets

\begin{tabular}{|l|l|l|l|l|l|}
\hline Diets & $\begin{array}{l}\text { Body mass } \\
\text { before SDA }(\mathrm{g})\end{array}$ & $\begin{array}{l}\text { Body mass } \\
\text { after SDA }(\mathrm{g})\end{array}$ & $\begin{array}{l}\mathrm{VO}_{2} \\
(\mathrm{ml} / \mathrm{min}\end{array}$ & $\begin{array}{l}\mathrm{VCO}_{2} \\
(\mathrm{ml} / \mathrm{min})\end{array}$ & $\mathrm{RQ}$ \\
\hline $\mathrm{HP}$ & $38.99 \pm 3.70^{\mathrm{a}}$ & $37.77 \pm 3.50^{\mathrm{a}}$ & $0.73 \pm 0.32^{\mathrm{c}}$ & $0.59 \pm 0.03^{\mathrm{b}}$ & $0.81 \pm 0.04^{\mathrm{a}}$ \\
\hline $\mathrm{HC}$ & $38.59 \pm 3.50^{\mathrm{a}}$ & $37.84 \pm 3.50^{\mathrm{a}}$ & $0.83 \pm 0.27^{\mathrm{b}}$ & $0.81 \pm 0.12^{\mathrm{a}}$ & $0.98 \pm 0.03^{\mathrm{a}}$ \\
\hline $\mathrm{MF}$ & $38.36 \pm 3.50^{\mathrm{a}}$ & $37.76 \pm 3.50^{\mathrm{a}}$ & $0.88 \pm 0.21^{\mathrm{a}}$ & $0.69 \pm 0.23^{\mathrm{b}}$ & $0.78 \pm 0.03^{\mathrm{a}}$ \\
\hline $\mathrm{HF}$ & $38.82 \pm 3.60^{\mathrm{a}}$ & $38.16 \pm 3.40^{\mathrm{a}}$ & $0.90 \pm 0.23^{\mathrm{a}}$ & $0.70 \pm 0.21^{\mathrm{b}}$ & $0.78 \pm 0.02^{\mathrm{a}}$ \\
\hline
\end{tabular}

Values are means $\pm \mathrm{SD} ; \mathrm{a}, \mathrm{b}, \mathrm{c}$ different at $P<0.05$.

Table 3: Energy devoted to SDA, gross energy intake and SDA responses in female mice

\begin{tabular}{|l|l|l|l|l|l|}
\hline Diets & $\begin{array}{l}\mathrm{VO}_{2} \\
\text { converted } \\
\text { energy }(\mathrm{kJ})\end{array}$ & $\begin{array}{l}\text { Dry food intake } \\
\text { at SDA }(\mathrm{g})\end{array}$ & $\begin{array}{l}\mathrm{GE} \text { intake at } \\
\text { SDA }(\mathrm{kJ})\end{array}$ & $\mathrm{C}_{\text {SDA }}$ & $\mathrm{C}_{\mathrm{SDA}}(\%)$ \\
\hline $\mathrm{HP}$ & $0.88 \pm 0.04^{\mathrm{b}}$ & $0.47 \pm 0.36^{\mathrm{b}}$ & $9.37 \pm 4.21^{\mathrm{a}}$ & $0.094 \pm 0.01^{\mathrm{a}}$ & $9.4^{\mathrm{a}}$ \\
\hline $\mathrm{HC}$ & $1.03 \pm 0.03^{\mathrm{a}}$ & $0.95 \pm 0.63^{\mathrm{ab}}$ & $16.91 \pm 3.43^{\mathrm{c}}$ & $0.061 \pm 0.02^{\mathrm{b}}$ & $6.1^{\mathrm{b}}$ \\
\hline $\mathrm{MF}$ & $1.06 \pm 0.02^{\mathrm{a}}$ & $1.19 \pm 0.32^{\mathrm{a}}$ & $27.24 \pm 5.61^{\mathrm{a}}$ & $0.039 \pm 0.01^{\mathrm{c}}$ & $3.9^{\mathrm{c}}$ \\
\hline $\mathrm{HF}$ & $1.08 \pm 0.03^{\mathrm{a}}$ & $1.04 \pm 0.29^{\mathrm{a}}$ & $24.03 \pm 5.27^{\mathrm{b}}$ & $0.044 \pm 0.01^{\mathrm{c}}$ & $4.5^{\mathrm{c}}$ \\
\hline
\end{tabular}

Values are means $\pm \mathrm{SD} ; \mathrm{a}, \mathrm{b}, \mathrm{c}, \mathrm{d}$ different at $P<0.05$

\section{DISCUSSION}

Metabolism includes maintenance cost, SDA and energy cost of an activity (Blaxter, 1989). Since mammals increase their oxygen consumption after feeding (Gawecki and Jeszka, 1978; McDonald et al., 2002; Mc Cue, 2006; Secor, 2009), the magnitude of the metabolic response to feeding is significant and deserves important practical consideration. The maximum value of oxygen consumption has been reported to increase over pre-feeding levels when assessing energy expenditure associated with feeding (Krieger, 1978; Abbott et al., 1990).

In the present study, the ingestion of $\mathrm{HP}, \mathrm{HC}$, MF and HF diets by MF1 mice was followed by increased losses of energy as heat. As a result, the SDA of the respective diets increased and reached the maximum level within 1.7 hours of feeding. The fact that the increased metabolism of mice fed on the respective diets was above the resting level indicates that the method of using macronutrient diets to investigate SDA in MF1 mice was feasible as reported in other animals (Kleiber, 1975; McDonald et al., 2002; McCue, 2006). The oxygen consumption of mammals and birds is known to increase abruptly to a maximum level after feeding (Krieger, 1978; Blaxter, 1989; Gabarrou et al., 1997; Secor, 2009). This is associated with the extra energy required for the transport of food through the alimentary tract, its digestion, absorption, and postabsorption metabolic processes associated with the ingestion of food (Kleiber, 1975; Gawecki and Jeszka, 1978; McDonald et al., 2002; Mc Cue, 2006; Secor, 2009). In this study, SDA varied between the mice fed on the HP, HC, MF and HF diets. This may depend on the weight of protein present in each diet. In terms of weight, HP diet contained a higher amount of protein $(60 \mathrm{~g} / 100 \mathrm{~g}$ diet) than the HC, MF and HF diets (approximately $20 \mathrm{~g} / 100 \mathrm{~g}$ diet). SDA in the mice was influenced by the composition of the HP, HC, MF and $\mathrm{HF}$ diets since the magnitude of SDA was different for each of the four diets fed to the mice. This corroborates some reports on published SDA responses in mammals ingesting various protein meals: dog fed on beef, SDA = $45 \%$ (William et al., 1912); dog fed on beef, SDA $=50 \%$ (Weiss and Rapport, 1924); human fed on protein meal, SDA = 17\% (Mason et al., 1927); rat fed on casein, SDA $=13 \%$ (Kriss et al., 1934); rat fed on casein, SDA $=13 \%$ (Kriss, 1938) and human fed on protein, SDA $=17 \%$ (Bradfield and Jourdan, 1973). The magnitudes of SDA are generally higher for mammals fed HP diets than those fed HC, MF and HF diets (McCue, 2006; Secor, 2009).

\section{CONCLUSION}

In conclusion, we have shown that the use of open-flow respirometry to measure the magnitude of SDA in laboratory mice fed different macronutrient diets was feasible. This study shows that SDA is an important factor in energy intake of mice since it is an unavoidable 'tax' on food processing. Again the results show that protein diet can elicit very high SDA response and that SDA after fat diet is low. Therefore, the magnitude of SDA depends not only on meal size and body mass of animals but also on the diet composition. To the best of our knowledge, this is the first time that 
SDA has been measured in laboratory mice using open-flow respirometry.

\section{ACKNOWLEDGEMENTS}

We thank Shona Fleming and Duncan Wood for animal husbandry. This experiment was authorized by a local ethical review committee and carried out under United Kingdom Home Office project licence PPL $60 / 2881$.

\section{REFERENCES}

Abbott, W. G. H., Howard, B. V., Ruotolo, G. and Ravussin, E., 1990. Energy expenditure in humans: effects of dietary fat and carbohydrate. Am. J. Physiol. 258 (Endocrinol. Metab. 21): E347 E351.

Arch, J. R. S., Hislop, D., Wang, S. J. Y. and Speakman, J. R., 2006. Some mathematical and technical issues in the measurement and interpretation of opencircuit indirect calorimetry in small animals. Internat. J. Obes. 30: 1322-13 31.

Bacigalupe, L. D. and Bozinovic, F., 2002. Design, limitations and sustained metabolic rate: lessons from small mammals. J. Exp. Biol. 205: 29632970.

Blaxter, K., 1989. Energy Metabolism in Animals and Man. Cambridge: Cambridge University Press.

Bradfield, R. B. and Jourdan, M. H. (1973). Relative importance of specific dynamic action in weightreduction diets. Lancet 2:640-643.

Gabarrou, J. F., Géreart, P. A., Picard, M. and Bodas, A., 1997. Diet-Induced Thermogenesis in Cockerels Is Modulated by Genetic Selection for High or Low Residual Feed Intake. J. Nutr. 127: 2371-2376.

Gawecki, J. and Jeszka, J., 1978. The effect of the extent of hydrolysis on casein on its specific dynamic action in the rat. Br. J. Nutr. 40: 465471.

Glenne, E. W. and Blair, O. W., 1995. Variation in the respiratory quotient of birds and implications for indirect calorimetry using measurements of carbon dioxide production. J. Exp. Biol. 198: 213-219.

Hardy, R. N., 1974. Temperature and Animal Life. The Institute of Biology's Studies in Biology no. 35.

Janes, D. N. and Chappell, M. A., 1995. The effect of ration size and body size on specific dynamic action in adelie penguin chicks, Pygoscelis adeliae. Physiol. Zoo. 68: 1029- 1044.

Jéquier, E., 1985. Nutrient-induced thermogenesis in man: its role in body weight regulation. $\mathrm{J}$. Physiol. 80: 129-140.
Karasov, W. H., 1986. Energetics, physiology and vertebrates ecology. Trends Ecol. Evol. 1: 101104.

Kleiber, M., 1975. The Fire of Life: An Introduction to Animal Energetics. Krieger, Huntington, NY, USA.

Krieger, I., 1978. Relation of specific dynamic action of food (SDA) to growth in rats. Am. J. Clinc. Nutr. 31: 767-768.

Kriss, M., 1938. The specific dynamic effects of proteins when added in different amounts to a maintenance diet. J. Nutr. 15: 565-581.

Kriss, M., Forbes, E. B. and Miller, R. C., 1934. The specific dynamic effects of protein, fat, and carbohydrate as determined with the albino rat at different planes of nutrition. J. Nutr. 8: 509534.

Król E, and Speakman J. R., 2003a. Limits to sustained energy intake VI. Energetics of lactation in laboratory mice at thermoneutrality. J. Exp.Biol. 206: 4255-4266.

Lusk, M., 1912. Metabolism after the ingestion of dextrose and fat, including the behaviour of water, urea and sodium chloride solutions. J. Biol. Chem. 13: 27-47.

Lusk, M., 1915. An investigation into the causes of the specific dynamic action of the foodstuffs. J. Biol. Chem. 20: 555-617.

Mason. E. H., Hill, E. and Charlton, D., 1927. Abnormal specific dynamic action of protein, glucose, and fat associated with undernutrition. J. Clin. Invest. 4, 353-387.

McCue, M. D., 2006. Specific dynamic action: A century of investigation. Comp. Biochem. Physiol. A 144: 381-394.

McDonald, P., Edwards, R. A., Greenhalgh, J. F. D. and Morgan, C. A., 2002. Animal Nurtition. Sixth edn. Prentice-Hall, Inc. London.

Pike , R. L. and Brown, M. L., 1984. Nutrition: An Integrated Approach. John Wiley \& Sons, New York.

Rapport, D., 1924. The relative specific dynamic action of various proteins. J. Biol. Chem. 60: 497-511.

Schmidt-Nielsen, K., 1997. Animal physiology. Adaptation and environment. $5^{\text {th }}$ edition. Cambridge University Press, Cambridge.

Secor, M., 2009. Specific dynamic action: a review of the postprandial metabolic response. J. Comp. Physiol. B. 179: 1-56. 
Speakman J. R, and McQueenie J., 1996. Limits to sustained metabolic rate: The link between food intake, basal metabolic rate and morphology in reproducing mice, Mus musculus. Physiol. Zool. 69: 746-769.

Speakman, J. R., 1997. Doubly Labelled Water: Theory and Practice. London: Chapman and Hall.

Speakman J. R., 2000. The cost of living: Field metabolic rates of small mammals. Adv. Ecol. Res. 30: 177-297.

Stenseth, N. C., Framstead, E., Migula, P., Trojan, P. and Wojciechowska-Trojan, B., 1980. Energy models for the common vole (Microtus arvalis): energy as a limiting resource for reproductive output. Oikos 34: 1-22.

Swennen, Q., Janssens, G. P., collin, A., Le BihanDuval. E., Verbeke, K., Decuypere, E and Buyse, J., 2006. Diet-induced thermogenesis and glucose oxidation in broiler chickens: influence of genotype and diet composition. Poultry Sci. 85: 731-742.
Taylor, C. M. and Pye, O. F., 1966. Foundations of Nutrition. MacMillan, New York.

Trier, T. M., 1996. Diet-induced thermogenesis in the prairie vole, Microtus ochrogaster. Physiol. Zool. 69: 1456-1468.

Weir, J. B. de V., 1949. New methods for calculating metabolic rates with special reference to protein metabolism. J. Physiol. Lond. 109: 1-9

Weiss, R. and Rapport. D., 1924. The inter-correlations between certain amino acids and proteins with reference to their specific dynamic action. J. Biol. Chem. 60: 513-544.

Whitney, E. N. and Rolfes, S. R., 1996. Understanding Nutrition. West, New York.

William, H. B., Riche, J. A. and Lusk, G., 1912. Metabolism of the dog following the ingestion of meat in large quantity. J. Biol. Chem. 12: 349381. 